\begin{tabular}{|c|l|}
\hline Title & $\begin{array}{l}\text { Descriptions of two new species of Rhizorhina Hansen, 1892 (Copepoda: Siphonostomatoida: Nicothoidae) parasitic on } \\
\text { tanaidacean crustaceans, with a note on their phy logenetic position }\end{array}$ \\
\hline Author(s) & Kakui, Keiichi \\
\hline Citation & $\begin{array}{l}\text { Systematic parasitology, 93(1), 57-68 } \\
\text { https:/doi.org/10.1007/311230-015-9604-x }\end{array}$ \\
\hline Issue Date & 2016-01 \\
\hline Doc URL & http://hdl.handle.net/2115/63931 \\
\hline Rights & The final publication is available at link.springer.com \\
\hline Type & article (author version) \\
\hline File Information & Descriptions of two new species of Rhizorhina Hansen.pdf \\
\hline
\end{tabular}

Instructions for use 


\title{
Descriptions of two new species of Rhizorhina Hansen, 1892 (Copepoda: Siphonostomatoida: Nicothoidae) parasitic on tanaidacean crustaceans, with a note on their phylogenetic position
}

\section{Keiichi Kakui}

Received: 9 June 2015 / Accepted: 22 September 2015

\author{
K. Kakui $(\bowtie)$ \\ Faculty of Science, Hokkaido University, Sapporo 060-0810, Japan \\ e-mail: kakui@mail.sci.hokudai.ac.jp
}

\begin{abstract}
Two new species of nicothoid copepod are described. Rhizorhina ohtsukai n. sp. found on a leptocheliid (Leptochelia sp.) collected at depths of 151-136 m in the North Pacific Ocean is most similar to Rhizorhina aesthetes Boxshall \& Harrison, 1988 but can be distinguished by the possession of a narrower body with a rounded anterior end, and in the position of the gonopores. Rhizorhina soyoae n. sp. found on an apseudid (Fageapseudes sp.) collected at depths of 1,595-1,557 m in East China Sea most closely resembles Rhizorhina tanaidaceae Gotto, 1984 but differs in having a narrower body with a rounded anterior end. Partial nucleotide sequences of the cytochrome $c$ oxidase subunit I (COI) gene were obtained from the two copepods in order to enable future barcoding. A phylogenetic reconstruction based on the 18S rRNA gene placed the copepods within the Siphonostomatoida Burmeister, 1835, with the nicothoid Choniosphaera maenadis (Bloch \& Gallien, 1933), and separate from the Rhizorhina spp. clade, suggesting that the family Nicothoidae Dana, 1849 is not monophyletic.
\end{abstract}


This is the third report of copepods parasitic on tanaidacean crustaceans.

\section{Introduction}

Copepods in the family Nicothoidae Dana, 1849 are parasitic, and are classified in 22 genera (Boxshall \& Halsey, 2004; Ohtsuka et al., 2005; Bamber \& Boxshall, 2006; Boyko, 2009). Among these genera, females of species of Rhizorhina Hansen, 1892 and Arhizorhina Bamber \& Boxshall, 2006 have the urosome incorporated into a swollen, globular body and lack mouthparts, but differ from each other in the shape of the mouth, or "stalk” (Bamber \& Boxshall, 2006), penetrating the host body. The stalk is narrow and rod-shaped in Rhizorhina and distally widened and funnel shaped in Arhizorhina (see Bamber \& Boxshall, 2006). To date, six species in Rhizorhina have been reported from representatives of four crustacean host groups: three on species of Isopoda Latreille, 1817, and one each on members of Leptostraca Claus, 1880, Amphipoda Latreille, 1816 and Tanaidacea Dana, 1849 (see Boxshall \& Harrison, 1988). Arhizorhina mekonicola Bamber \& Boxshall, 2006, the sole member of the genus, was collected from a tanaidacean host (Bamber \& Boxshall, 2006).

During faunal surveys in the North Pacific Ocean and East China Sea in 2014, I obtained four specimens of Rhizorhina spp. parasitic on tanaidaceans; this is the third report of copepod parasites utilising Tanaidacea. These copepods turned out to represent two undescribed species, which are described herein. For both species, partial sequences of the cytochrome $c$ oxidase subunit I (COI) gene were obtained to aid future DNA barcoding, and partial sequences of the 18S rRNA (18S) gene were generated and used to assess the phylogenetic position of the new species within the Siphonostomatoida Burmeister, 1835. 


\section{Materials and methods}

Two infected tanaidaceans from the North Pacific Ocean were obtained with a biological dredge from the TR/V Seisui-maru (Mie University), at depths of 151-136 m; the hosts were Leptochelia sp. in the family Leptocheliidae Lang, 1973. An infected animal from the East China Sea was collected with a small plankton net attached inside a larger beam trawl (see figure 2B in Akiyama et al., 2008) from the R/V Soyo-maru (National Research Institute of Fishery Science), at depths of 1,595-1,557 m; the host was Fageapseudes sp. in the family Apseudidae Leach, 1814. The three tanaidaceans were fixed and preserved in $70 \%$ ethanol.

Host animals were dissected with chemically sharpened tungsten needles to detach the copepods. One egg-sac of each copepod species was placed in 99\% ethanol for DNA extraction. Detached copepods in ethanol were mounted on a concavity slide (Plate for Blood Test; Sansyo Co., Ltd., Tokyo, Japan), covered with a coverslip, and photographed at different focal planes through an OLYMPUS BX51 light microscope. The serial images were assembled by using CombineZM (Hadley, 2008) and subsequently processed with Adobe Photoshop/Illustrator CS6. Measurements were made with ImageJ (Rasband, 2014). The copepods were then transferred into c.10\% glycerin in $70 \%$ ethanol and mounted on a glass slide with a pair of coverslip spacers, and their holdfast and gonopore were observed with the BX51. Illustrations were prepared with Adobe Illustrator CS6 from draft line drawings made with a camera lucida and/or from digital micrograph images. After observation, the copepods were stored in $70 \%$ ethanol.

The terminology for the orientation and morphology of the tanaidaceans follows Larsen (2003). All measurements in the text are in micrometres, unless noted otherwise. Body length (BL) was measured from the base of the antennule to the tip of the pleotelson in the tanaidaceans, and from the anterior to posterior edges of the body in the copepods; body width (BW) was measured at the widest portion of the carapace (tanaidaceans) or body (copepods); body thickness (BT) was measured at the thickest portion of body in copepods. 
Total DNA was extracted from an egg-sac by using a DNeasy Brood \& Tissue Kit (Qiagen GmbH, Hilden, Germany). Table 1 lists the primers used for the polymerase chain reaction (PCR) amplification and cycle sequencing. PCR amplification conditions were $95^{\circ} \mathrm{C}$ for $1 \mathrm{~min}$; 35 cycles of $95^{\circ} \mathrm{C}$ for $30 \mathrm{~s}, 50^{\circ} \mathrm{C}$ for $30 \mathrm{~s}$, and $72^{\circ} \mathrm{C}$ for $1 \mathrm{~min}$ (COI) or $2.5 \mathrm{~min}$ (18S); and $72^{\circ} \mathrm{C}$ for 7 min. All nucleotide sequences were determined by direct sequencing with a BigDye Terminator Kit ver. 3.1 and a 3130 or 3730 Genetic Analyzer (Life Technologies, California, USA). The $18 \mathrm{~S}$ dataset comprising 62 terminal taxa (including the two species described herein) was aligned by using MAFFT version 7 (Katoh \& Standley, 2013) with the “Auto” strategy (“L-INS-i” selected; Katoh et al., 2005); ambiguous sites were then removed by using trimAl (Capella-Gutiérrez et al., 2009) with the option “automated1”. The aligned sequences were trimmed in MEGA 5.2 (Tamura et al., 2011) to a length of 1,637 nt, the shortest length among the sequences. The optimal substitution model was GTR + I + G, determined under the Akaike information criterion (Akaike, 1974) with jModelTest 2.1.4 (Darriba et al., 2012) and Kakusan4 version 4.0.2012.12.14 (Tanabe, 2011). No significant nucleotide compositional heterogeneity was detected (Chi-square test in Kakusan4: $\mathrm{p}=1.00000)$. A maximum likelihood $(\mathrm{ML})$ analysis was conducted in RAxML version 8.1.5 (Stamatakis, 2014), assisted with phylogears2 version 2.0.2013.10.22 (Tanabe, 2008), and nodal support values were obtained through ML analyses of 1,000 bootstrap pseudoreplicates (Felsenstein, 1985).

\section{Family Nicothoidae Dana, 1849}

Genus Rhizorhina Hansen, 1892

\section{Rhizorhina ohtsukai n. sp.}

Type-host: Leptochelia sp. (Tanaidacea: Paratanaoidea: Leptocheliidae). 
Type-locality: Off Owase, Kumano Sea, Japan, North Pacific Ocean $\left(34^{\circ} 09.228^{\prime} \mathrm{N}, 136^{\circ} 49.751^{\prime} \mathrm{E}\right.$ to $\left.34^{\circ} 09.513^{\prime} \mathrm{N}, 136^{\circ} 49.740^{\prime} \mathrm{E}\right)$, depths of $151-136 \mathrm{~m}$.

Attachment site: The ventral side of the pereonite or pleonite.

Type-material: Holotype (ZIHU-5030; 1 vial): ovigerous female $(\mathrm{BL}=333 \mu \mathrm{m} ; \mathrm{BW}=278 \mu \mathrm{m})$ attached to ventral side of pleonite 1 of female Leptochelia sp. $(\mathrm{BL}=3.13 \mathrm{~mm}$; BW $=0.43 \mathrm{~mm})$, detached from host; TR/V Seisui-maru, Off Owase, Kumano Sea, Japan, North Pacific Ocean $\left(34^{\circ} 09.2288^{\prime} \mathrm{N}, 136^{\circ} 49.751^{\prime} \mathrm{E}\right.$ to $\left.34^{\circ} 09.513^{\prime} \mathrm{N}, 136^{\circ} 49.740^{\prime} \mathrm{E}\right), 151-136 \mathrm{~m}$ depth, biological dredge, 30.x.2014, collected by K. Kakui. Paratype (ZIHU-5031, 1 vial): 1 non-ovigerous female attached to ventral side of pereonite 3 of female Leptochelia sp. $(\mathrm{BL}=3.04 \mathrm{~mm}$; $\mathrm{BW}=0.43$ $\mathrm{mm})$, not detached from host. Collection data as for the holotype.

Representative sequences: The COI (660 nt, 219 deduced amino acids) and 18S (1,760 nt) sequences were determined from the right egg-sac of the holotype specimen; the DNA Data Bank of Japan (DDBJ) accession numbers are LC054032 (COI) and LC054034 (18S). Etymology: The species is named for Susumu Ohtsuka in recognition of his great contributions to the knowledge of copepod biology.

Description (Figs. 1-4)

Ovigerous female [Based on the holotype.] Body (Figs. 1-3, 4A) oval but slightly flattened dorsoventrally; anterior margin rounded, without swelling (sensu Boxshall \& Harrison, 1988); posterior protrusion absent. Body 333 long, 278 wide, 235 thick $(\mathrm{BL} / \mathrm{BW}=1.20$; BW/BT = 1.18). Rod-shaped stalk located in ventral, subanterior region of body (Fig. 3C), connecting branching holdfast (Fig. 4B). Gonopores opening on ventral surface; separation between left and right gonopores 170 (Fig. 3D), 0.61× BW. Gonopore surrounded by thicker region (Fig. 4C). Egg-sac prolate spheroidal (Fig. 3E), containing c.10 eggs, 80 in diameter. 
Remarks

Rhizorhina ohtsukai n. sp. is the seventh species described in Rhizorhina, and the first copepod known to parasitise paratanaoid tanaidaceans. It most resembles Rhizorhina aesthetes Boxshall \& Harrison, 1988 in having the body longer than wide and the gonopores opening on the ventral surface of the body. However, Rhizorhina ohtsukai n. sp. differs from R. aesthetes in the shape of anterior margin of the body (rounded in R. ohtsukai n. sp.; the anterior portion of the body, together with the rod-shaped stalk located in the anterior region of the body, protruding as a tapering anterior swelling in $R$. aesthetes), in having a narrower body (BL/BW 1.20 vs 1.08), and in the position of the gonopores (more laterally in $R$. ohtsukai n. sp., separated by $0.61 \times$ BW vs $0.47 \times$ BW in $R$. aesthetes). The host crustaceans also differ (a tanaidacean for $R$. ohtsukai n. sp. vs an isopod for R. aesthetes) (see Boxshall \& Harrison, 1988). Differences among all congeners are summarised in Table 2.

\section{Rhizorhina soyoae n. sp.}

Type-host: Fageapseudes sp. (Tanaidacea: Apseudoidea: Apseudidae).

Type-locality: East China Sea $\left(27^{\circ} 30.458^{\prime} \mathrm{N}, 126^{\circ} 58.182^{\prime} \mathrm{E}\right.$ to $\left.27^{\circ} 30.797^{\prime} \mathrm{N}, 126^{\circ} 58.067^{\prime} \mathrm{E}\right)$, depths of 1,595-1,557 m.

Attachment site: The lateral or dorsal surface of the pereonite.

Type-material: Holotype (ZIHU-5032; 1 vial): ovigerous female $(\mathrm{BL}=461 \mu \mathrm{m} ; \mathrm{BW}=455 \mu \mathrm{m})$ attached to right side of pereonite 3 of male Fageapseudes sp. $(\mathrm{BL}=8.79 \mathrm{~mm}$; $\mathrm{BW}=0.74 \mathrm{~mm})$, detached from host; R/V Soyo-maru, Stn kago-9, East China Sea $\left(27^{\circ} 30.458^{\prime} \mathrm{N}, 126^{\circ} 58.182^{\prime} \mathrm{E}\right.$ to $\left.27^{\circ} 30.797^{\prime} \mathrm{N}, 126^{\circ} 58.067^{\prime} \mathrm{E}\right), 1,595-1,557 \mathrm{~m}$ depth, plankton net in beam trawl, 26.vii.2014, collected by K. Kakui. Paratype (ZIHU-5033, 1 vial): 1 non-ovigerous female attached to dorsal 
surface of pereonite 5 of male Fageapseudes sp. (same host individual as for holotype), not detached from host. Collection data as for the holotype.

Representative sequences: The COI (658 nt, 219 deduced amino acids) and 18S (1,760 nt) sequences were determined from the left egg-sac of the holotype specimen; the DDBJ accession numbers are LC054033 (COI) and LC054035 (18S).

Etymology: The specific name is from R/V Soyo-maru, the vessel from which the type-specimens were collected.

Description (Figs. 5-8)

Ovigerous female [Based on the holotype.] Body (Figs. 5-8) roughly spherical, but widened posteriorly and slightly flattened dorsoventrally; anterior margin rounded, without swelling; posterior protrusion present. Body (including posterior protrusion) 461 long, 455 wide, 384 thick $(\mathrm{BL} / \mathrm{BW}=1.01 ; \mathrm{BW} / \mathrm{BT}=1.18)$. Rod-shaped stalk located in ventral, subanterior region of body (cf., Fig. 6), connecting branching holdfast. Gonopores opening on slight posterior hump on posterior surface (Figs. 7E, 8B); separation between left and right gonopores 185 (Fig. 7E), 0.40× BW. Egg-sac nearly spherical (Fig. 7A, C), holding c.25 eggs, 90 in diameter.

Remarks

Rhizorhina soyoae n. sp. is the eighth species described in Rhizorhina. It closely resembles Rhizorhina serolis Green, 1959 and Rhizorhina tanaidaceae Gotto, 1984 in having a posterior protrusion between the gonopores. However, Rhizorhina soyoae n. sp. differs from $R$. serolis in body size (BL $461 \mu \mathrm{m}$ vs 2,000 $\mu \mathrm{m}$; BW $455 \mu \mathrm{m}$ vs 2,500 $\mu \mathrm{m}$ ) and in the shape of the anterior margin (rounded vs concave) and egg-sacs (roughly spherical vs prolate spheroidal). The hosts are also different (a tanaidacean for $R$. soyoae n. sp. and an isopod for $R$. serolis) (see Green, 
1959).

Rhizorhina soyoae $\mathrm{n}$. sp. is also very similar to $R$. tanaidaceae but differs from the latter in having a narrower body (BL/BW 1.01 vs 0.84) and in the shape of the anterior margin (rounded vs straight). The hosts for the two species are both in the family Apseudidae, but in different genera [Fageapseudes sp. for R. soyoae n. sp.; Leviapseudes hanseni (Lang, 1968) for R. tanaidaceae] (see Gotto, 1984). Differences among all congeners are summarised in Table 2.

Except for $R$. soyoae n. sp., all copepod parasites reported on Tanaidacea (including $R$. ohtsukai n. sp. described above) attach to the ventral surface of the females (e.g. Fig. 1). They might be harmful for the host reproduction, as previously suggested (Ohtsuka et al., 2007), because tanaidaceans mate facing each other ventrally, and females form a marsupium on the ventral surface to brood eggs. The two specimens of $R$. soyoae n. sp., however, attached on the lateral and dorsal surfaces of the male host (Fig. 5); while they may not affect the host's mating behaviour, they might negatively affect its growth and/or sexual maturation; their attachment induced a lesion on the host exoskeleton (Fig. 6, arrowhead). More infected tanaidaceans are needed to confirm whether the infection sites I observed for $R$. soyoae n. sp. are typical.

\section{Phylogeny}

The only previous molecular phylogeny examining the phylogenetic position of Nicothoidae in Siphonostomatoida placed Nicothoidae in a clade with Dirivultidae Humes \& Dojiri, 1981, with weak branch support (Huys et al., 2007). The monophyly of the Nicothoidae, however, has not been tested because Huys et al. (2007) included only one nicothoid taxon, Choniosphaera maenadis (Bloch \& Gallien, 1933). The phylogenetic analysis in the present study included species in two nicothoid genera, Choniosphaera Connolly, 1929 (C. maenadis) and Rhizorhina (R. ohtsukai n. sp. and R. soyoae n. sp.), allowing a weak test of nicothoid monophyly. 
The present 18S dataset included two or more species each for nine of 18 ingroup families (Asterocheridae Giesbrecht, 1899, Caligidae Burmeister, 1835, Dirivultidae, Eudactylinidae C. B. Wilson, 1922, Hatchekiidae Kabata, 1979, Kroyeriidae Kabata, 1979, Larnaeopodidae Milne Edwards, 1840, Nicothoidae, and Pandaridae Milne Edwards, 1840) (see Table 3 for details). The ML tree (Fig. 9) strongly supported the monophyly of eight of these families, but did not recover Nicothoidae as monophyletic. The two species of Rhizorhina comprised a clade with $100 \%$ bootstrap support (BS), and this in turn formed a weakly supported (BS 35.8\%) clade with Ecbathyriontidae Humes, 1987 and Diribultidae. The other nicothoid, $C$. maenadis, appeared as the sister group to the Asterocheridae, though with very weak nodal support (BS 14.8\%). The relationships between Rhizorhina + Ecbathyriontidae + Diribultidae and Choniosphaera + Asterocheridae were unresolved.

Each of the two nicothoid genera exhibits a peculiar trait within the family Nicothoidae. Females of Rhizorhina spp. lack mouthparts but instead bear a "stalk" (Bamber \& Boxshall, 2006), a trait shared only with species of Arhizorhina. Choniosphaera is one of two genera in which the offspring hatch as a nauplius (Wakabayashi et al., 2013). Boxshall \& Lincoln (1983) placed Rhizorhina and Choniosphaera into two different species groups, the Rhizorhina and the Nicothoe group, respectively, among the three species groups they proposed in Nicothoidae (the third being the Sphaeronella group); the three groups were based mainly on the host taxon and character states for the antennules and maxillipeds, and “may represent natural groups” (see p. 899 in Boxshall \& Lincoln, 1983). The separation of Rhizorhina and Choniosphaera in the present $18 \mathrm{~S}$ tree possibly reflects the differences in morphology and developmental pattern mentioned above.

Acknowledgements I thank Taeko Kimura, Shoichi Kimura, Ken Fujimoto and Hideki Kaeriyama for providing specimens used in this study; Captains Makoto Uchida of TR/V 
Seisui-maru and Shiro Sawadaishi of R/V Soyo-maru and the crews of the two vessels for their kind support during the cruises; Hiroshi Kajihara for providing laboratory facilities; Susumu Ohtsuka for valuable comments on an early draft; two anonymous reviewers for improving the manuscript; and Matthew H. Dick for reviewing and editing the manuscript.

\section{Compliance with ethical standards}

Conflict of interest The author declares that he has no conflict of interest.

Ethical approval All applicable institutional, national and international guidelines for the care and use of animals were followed.

\section{References}

Akaike, H. (1974). A new look at the statistical model identification. IEEE Transactions on Automatic Control, 19, 716-723.

Akiyama, T., Shimomura, M., \& Nakamura, K. (2008). [Collection of deep-sea small arthropods: gears for collection and processing of samples on deck.] Taxa, 24, 27-32 (In Japanese with English abstract).

Bamber, R. N., \& Boxshall, G. A. (2006). A new genus and species of the Langitanainae (Crustacea: Peracarida: Tanaidacea: Tanaidae) bearing a new genus and species of nicothoid parasite (Crustacea: Copepoda: Siphonostomatoida: Nicothoidae) from the New Caledonia slope. Species Diversity, 11, 137-148.

Boxshall, G. A., \& Halsey, S. H. (2004). An introduction to copepod diversity. London: The Ray Society. 
Boxshall, G. A., \& Harrison, K. (1988). New nicothoid copepods (Copepoda:

Siphonostomatoida) from an amphipod and from deep-sea isopods. Bulletin of the British Museum (Natural History), Zoology, 54, 285-299.

Boxshall, G. A., \& Lincoln, R. J. (1983). Some new parasitic copepods (Siphonostomatoida: Nicothoidae) from deep-sea asellote isopods. Journal of Natural History, 17, 891-900.

Boyko, C. B. (2009). Nomenclatural issues with Paranicothoe Carton, 1970 and Pseudonicothoe Avdeev \& Avdeev, 1978 (Crustacea: Copepoda: Nicothoidae), with comments on the female isopod type specimen of Paranicothoe cladocera Carton, 1970. Proceedings of the Biological Society of Washington, 122, 206-211.

Capella-Gutiérrez, S., Silla-Martínez, J. M., \& Gabaldón, T. (2009). trimAl: a tool for automated alignment trimming in large-scale phylogenetic analyses. Bioinformatics, 25, 1972-1973.

Darriba, D., Taboada, G. L., Doallo, R., \& Posada, D. (2012). jModelTest 2: more models, new heuristics and parallel computing. Nature Methods, 9, 772.

Dippenaar, S. M. (2009). Estimated molecular phylogenetic relationships of six siphonostomatoid families (Copepoda) symbiotic on elasmobranchs. Crustaceana, 82, 1547-1567.

Felsenstein, J. (1985). Confidence limits on phylogenies: an approach using the bootstrap. Evolution, 39, 783-791.

Folmer, O., Black, M., Hoeh, W., Lutz, R., \& Vrijenhoek, R. (1994). DNA primers for amplification of mitochondrial cytochrome $c$ oxidase subunit I from diverse metazoan invertebrates. Molecular Marine Biology and Biotechnology, 3, 294-299.

Freeman, M. A., Anshary, H., \& Ogawa, K. (2013). Multiple gene analyses of caligid copepods indicate that the reduction of a thoracic appendage in Pseudocaligus represents convergent evolution. Parasites \& Vectors, 6, 336.

Green, J. (1959). Sphaeronella serolis Monod, and a new species of Rhizorhina, copepods parasitic on the isopod Serolis bromleyana Suhm (Crustacea). Proceedings of the 
Zoological Society of London, 132, 647-654.

Gotto, R. V. (1984). Two new species of Rhizorhina (Copepoda: Siphonostomatoida) from leptostracan and tanaidacean hosts. Journal of Natural History, 18, 811-817.

Hadley, A. (2008). CombineZM [software]. http://www.hadleyweb.pwp.blueyonder.co.uk/. Accessed 1 December 2014.

Huys, R., Llewellyn-Hughes, J., Conroy-Dalton, S., Olson, P. D., Spinks, J. N., \& Johnston, D. A. (2007). Extraordinary host switching in siphonostomatoid copepods and the demise of the Monstrilloida: integrating molecular data, ontogeny and antennulary morphology. Molecular Phylogenetics and Evolution, 43, 368-378.

Huys, R., Llewellyn-Hughes, J., Olson, P. D., \& Nagasawa, K. (2006). Small subunit rDNA and Bayesian inference reveal Pectenophilus ornatus (Copepoda incertae sedis) as highly transformed Mytilicolidae, and support assignment of Chondracanthidae and Xarifiidae to Lichomolgoidea (Cyclopoida). Biological Journal of the Linnean Society, 87, 403-425.

Jones, S. R., Prosperi-Porta, G., Kim, E., Callow, P., \& Hargreaves, B. (2006). The occurrence of Lepeophtheirus salmonis and Caligus clemensi (Copepoda: Caligidae) on three-spine stickleback Gasterosteus aculeatus in coastal British Columbia. Journal of Parasitology, 92, 473-480.

Katoh, K., \& Standley, D. M. (2013). MAFFT multiple sequence alignment software version 7: improvements in performance and usability. Molecular Biology and Evolution, 30, 772-780.

Katoh, K., Kuma, K., Toh, H., \& Miyata, T. (2005). MAFFT version 5: improvement in accuracy of multiple sequence alignment. Nucleic Acids Research, 33, 511-518.

Larsen, K. (2003). Proposed new standardized anatomical terminology for the Tanaidacea (Peracarida). Journal of Crustacean Biology, 23, 644-661.

Maraun, M., Erdmann, G., Schulz, G., Norton, R. A., Scheu, S., \& Domes, K. (2009). Multiple 
convergent evolution of arboreal life in oribatid mites indicates the primacy of ecology. Proceedings of the Royal Society B, 276, 3219-3227.

Nakayama, T., Watanabe, S., Mitsui, K., Uchida, H., \& Inoue, I. (1996). The phylogenetic relationship between the Chlamydomonadales and Chlorococcales inferred from 18SrDNA sequence data. Phycological Research, 44, 47-55.

Ohtsuka, S., Boxshall, G. A., \& Harada, S. (2005). A new genus and species of nicothoid copepod (Crustacea: Copepoda: Siphonostomatoida) parasitic on the mysid Siriella okadai Ii from off Japan. Systematic Parasitology, 62, 65-81.

Ohtsuka, S., Harada, S., Shimomura, M., Boxshall, G. A., Yoshizaki, R., Uyeno, D., Nitta, Y., Iwasaki, S., Okawachi, H., \& Sakakihara, T. (2007). Temporal partitioning: dynamics of alternating occupancy of a host microhabitat by two different crustacean parasites. Marine Ecology Progress Series, 348, 261-272.

Puitika, T., Kasahara, Y., Miyoshi, N., Sato, Y., \& Shimano, S. (2007). A taxon-specific oligonucleotide primer set for PCR-based detection of soil ciliate. Microbes and Environments, 22, 78-81.

Rasband, W. S. (2014). ImageJ [software]. http://imagej.nih.gov/ij. Accessed 1 December 2014. Stamatakis, A. (2014). RAxML version 8: a tool for phylogenetic analysis and post-analysis of large phylogenies. Bioinformatics, 30, 1312-1313.

Tamura, K., Peterson, D., Peterson, N., Stecher, G., Nei, M., \& Kumar, S. (2011). MEGA5: Molecular evolutionary genetics analysis using maximum likelihood, evolutionary distance, and maximum parsimony methods. Molecular Biology and Evolution, 28, 2731-2739.

Tanabe, A. S. (2008). Phylogears2 version 2.0.2013.10.22 [software]. http://www.fifthdimension.jp. Accessed 1 December 2014.

Tanabe, A. S. (2011). Kakusan4 and Aminosan: two programs for comparing nonpartitioned, proportional and separate models for combined molecular phylogenetic analyses of 
multilocus sequence data. Molecular Ecology Resources, 11, 914-921.

Wakabayashi, K., Otake, S., Tanaka, Y., \& Nagasawa, K. (2013). Choniomyzon inflatus n. sp. (Crustacea: Copepoda: Nicothoidae) associated with Ibacus novemdentatus (Crustacea: Decapoda: Scyllaridae) from Japanese waters. Systematic Parasitology, 84, 157-165.

\section{Figure legends}

Fig. 1 Rhizorhina ohtsukai n. sp. parasitising female Leptochelia sp., fresh specimens. A, B, E, Holotype, ovigerous female, ventral (A) and left ventral (B, E) views of host; C, D, F, Paratype, non-ovigerous female, ventral (C) and left ventral (D, F) views of host. Arrowheads indicate $R$. ohtsukai. Scale-bars: $0.5 \mathrm{~mm}$

Fig. 2 Rhizorhina ohtsukai n. sp. Holotype, penetrating ventral region of pleonite 1 of host (dissected), fixed specimen. Abbreviations: p6, pereonite 6; pl1, pleonite 1; rs, rod-shaped stalk. Scale-bar: $0.1 \mathrm{~mm}$

Fig. 3 Rhizorhina ohtsukai n. sp. Holotype, fixed specimen. A-C, Habitus, dorsal (A), ventral (B), and left (C) views; D, Ventral view of posterior region, showing positions of gonopores (arrowheads); E, Right egg-sac. Scale-bars: $0.1 \mathrm{~mm}$

Fig. 4 Rhizorhina ohtsukai n. sp. Holotype, line drawings from fixed specimen. A, Habitus, dorsal view (arrow indicates the rod-shaped stalk located in ventral, subanterior region of body); B, Rod-shaped stalk (arrow) and branching holdfast, ventral view; C, Left gonopore and surrounding wall-like structures, ventral view. Abbreviations: an, anterior; po, posterior; es, empty egg-sac. Arrowhead indicates region where possible copulatory pore is located. 
Scale-bars: A, $0.1 \mathrm{~mm}$; B, C, $0.05 \mathrm{~mm}$

Fig. 5 Rhizorhina soyoae n. sp. parasitising male Fageapseudes sp., fresh specimens. A, B, Two copepods on host, habitus, dorsal and right views of host, respectively; C, D, Non-ovigerous (paratype) and ovigerous (holotype) females, respectively, right view of host. Abbreviations: $n f$, non-ovigerous female; of, ovigerous female. Scale-bars: $1 \mathrm{~mm}$

Fig. 6 Rhizorhina soyoae n. sp. Holotype, with induced lesion on host exoskeleton (arrowhead), fixed specimen. Abbreviation: rs, rod-shaped stalk. Scale-bar: $0.1 \mathrm{~mm}$

Fig. 7 Rhizorhina soyoae n. sp. Holotype, fixed specimen. A-C, Habitus, dorsal (A), ventral (B), and left posterior (C) views; D, E, Posterior region, dorsal (D) and ventral (E) views. Black arrow indicates rod-shaped stalk. Black arrowheads indicate structure that may be remnant of male cephalic shield. White arrowheads indicate gonopores. Scale-bars: $0.1 \mathrm{~mm}$

Fig. 8 Rhizorhina soyoae n. sp. Holotype, line drawing of fixed specimen. A, Habitus, dorsal view, with arrow indicating rod-shaped stalk located in ventral, subanterior region of body; B, Left gonopore, ventral view. Abbreviations: an, anterior; po, posterior. Arrowhead indicates opening of gonopore. Scale-bars: $0.1 \mathrm{~mm}$

Fig. 9 Tree from ML analysis of 18S sequences (1,637 nt), including sequences from $R$. ohtsukai n. sp. and $R$. soyoae n. sp. Clades containing more than two confamilial terminal taxa were collapsed (terminal triangles), except for those in the Dirivultidae and Nicothoidae. Numbers near nodes are bootstrap values in percent. Family names are indicated in capital letters. 
Table 1 List of PCR and cycle sequencing (CS) primers used in this study

\begin{tabular}{lllll}
\hline Marker & Primer & Sequence (5' to 3') & Reaction & Source \\
\hline COI & LCO1490 & GGTCAACAAATCATAAAGATATTGG & PCR \& CS & Folmer et al. (1994) \\
& HCO2198 & TAAACTTCAGGGTGACCAAAAAATCA & PCR \& CS & Folmer et al. (1994) \\
\multirow{2}{*}{ 18S } & SR1 & TACCTGGTTGATCCTGCCAG & PCR & Nakayama et al. (1996) \\
& SR8 & GGATTGACAGATTGAGAGCT & CS & Nakayama et al. (1996) \\
& SR9 & AACTAAGAACGGCCATGCAC & CS & Nakayama et al. (1996) \\
& SR10 & AGGTCTGTGATGCCCTTAGA & CS & Nakayama et al. (1996) \\
& SR12 & CCTTCCGCAGGTTCACCTAC & PCR \& CS & Nakayama et al. (1996) \\
& EU929R & TTGGCAAATGCTTTCGC & CS & Puitika et al. (2007) \\
& 18S554f & AAGTCTGGTGCCAGCAGCGCG & CS & Maraun et al. (2009) \\
& 18S614r & TCCAACTACGAGCTTTTTAACC & CS & Maraun et al. (2009) \\
\hline
\end{tabular}


Table 2 Comparison of key characters for females of species of Rhizorhina, with information on hosts

\begin{tabular}{|c|c|c|c|c|c|c|c|c|c|c|}
\hline Species & $\mathrm{BL}$ & BW & $\mathrm{BL} / \mathrm{BW}$ & Body shape & $\begin{array}{l}\text { Anterior } \\
\text { margin of body }\end{array}$ & $\begin{array}{l}\text { Posterior } \\
\text { protrusion }\end{array}$ & $\begin{array}{l}\text { Gonopores } \\
\text { Position }\end{array}$ & Separation & Egg-sac shape & Host \\
\hline R. ohtsukai n. sp. & 333 & 278 & 1.20 & subspherical & rounded & absent & ventral & 170 & spheroidal & Tanaidacea \\
\hline R. soyoae n. sp. & 461 & 455 & 1.01 & subspherical & rounded & present & posterior & 185 & $\begin{array}{l}\text { almost } \\
\text { spherical }\end{array}$ & Tanaidacea \\
\hline $\begin{array}{l}\text { R. aesthetes Boxshall \& } \\
\text { Harrison, } 1988\end{array}$ & 304 & 282 & 1.08 & subspherical & with swelling & absent & ventral & 132 & - & Isopoda \\
\hline R. ampeliscae Hansen, 1892 & 960 & 1,050 & 0.91 & subspherical & with swelling & absent & posterior & 187 & $\begin{array}{l}\text { almost } \\
\text { spherical }\end{array}$ & Amphipoda \\
\hline $\begin{array}{l}\text { R. hystrix Boxshall \& } \\
\text { Harrison, } 1988\end{array}$ & 788 & 859 & 0.92 & subspherical & with swelling & absent & posterior & 353 & - & Isopoda \\
\hline R. leptostracae Gotto, 1984 & 521 & 552 & 0.94 & discoid & concaved & absent & posterior & 205 & spherical & Leptostraca \\
\hline R. serolis Green, 1959 & 2,000 & 2,500 & 0.80 & subrectangular & concaved & present & posterior & 1,200 & spheroidal & Isopoda \\
\hline R. tanaidaceae Gotto, 1984 & 500 & 594 & 0.84 & subrectangular & straight & present & posterior & 258 & - & Tanaidacea \\
\hline
\end{tabular}

Abbreviations: BL, body length; BW, body width 
Table 3 Copepod species included in the $18 \mathrm{~S}$ analysis in this study

\begin{tabular}{|c|c|c|c|}
\hline Family & Taxon & $\begin{array}{l}\text { GenBank } \\
\text { accession } \\
\text { no. }\end{array}$ & Reference \\
\hline \multirow[t]{2}{*}{ Asterocheridae } & Asterocheidae sp. 1 & AY627018 & Huys et al. (2006) \\
\hline & Orecturus sp. & AY627017 & Huys et al. (2006) \\
\hline \multirow[t]{12}{*}{ Caligidae } & Gloiopotes watsoni Kirtisinghe, 1934 & AY627019 & Huys et al. (2006) \\
\hline & Lepeophtheirus salmonis (Krøyer, 1837) & AF208263 & Huys et al. (2007) \\
\hline & Lepeophtheirus hippoglossi (Krøyer, 1837) & DQ538503 & Huys et al. (2007) \\
\hline & Lepeophtheirus hospitalis Fraser, 1920 & DQ123831 & Jones et al. (2006) \\
\hline & $\begin{array}{l}\text { Lepeophtheirus natalensis Kensley \& Grindley, } \\
1973\end{array}$ & FJ447440 & Dippenaar (2009) \\
\hline & Lepeophtheirus parvicruris Fraser, 1920 & DQ123830 & Jones et al. (2006) \\
\hline & Caligus clemensi Oarker \& Margolis, 1964 & DQ123833 & Jones et al. (2006) \\
\hline & Caligus elongatus Nordmann, 1932 & AY627020 & Huys et al. (2006) \\
\hline & Caligus fugu (Yamaguti, 1936) & KC569364 & Freeman et al. (2013) \\
\hline & Caligus uniartus (Ho et al., 2004) & КС569363 & Freeman et al. (2013) \\
\hline & Paralebion elongatus C. B. Wilson, 1911 & FJ447441 & Dippenaar (2009) \\
\hline & Alebion sp. & FJ447442 & Dippenaar (2009) \\
\hline Cancerillidae & Cancerillidae sp. & AY627021 & Huys et al. (2006) \\
\hline Dichelesthiidae & Anthosoma crassum (Abildgaard, 1794) & FJ447459 & Dippenaar (2009) \\
\hline Dinopontiidae & Stenopontius sp. & AY627022 & Huys et al. (2006) \\
\hline \multirow[t]{3}{*}{ Dirivultidae } & Aphotopontius mammilatus Humes, 1987 & DQ538508 & Huys et al. (2007) \\
\hline & Ceuthoecetes sp. & DQ538506 & Huys et al. (2007) \\
\hline & Rhogobius contractus Humes, 1987 & AY627023 & Huys et al. (2006) \\
\hline Dissonidae & Dissonus manteri Kabata, 1966 & DQ538500 & Huys et al. (2007) \\
\hline Ecbathyriontidae & Ecbathyrion prolixicauda Humes, 1987 & AY627024 & Huys et al. (2006) \\
\hline \multirow[t]{5}{*}{ Eudactylinidae } & Eudactylina pusilla Cressey, 1967 & FJ447439 & Dippenaar (2009) \\
\hline & Eudactylinodes niger (C. B. Wilson, 1905) & FJ447438 & Dippenaar (2009) \\
\hline & Nemesis lamna Risso, 1826 & FJ447431 & Dippenaar (2009) \\
\hline & Nemesis sp. 3 & FJ447435 & Dippenaar (2009) \\
\hline & Nemesis sp. 4 & FJ447436 & Dippenaar (2009) \\
\hline \multirow[t]{2}{*}{ Hatschekiidae } & Hatschekia pagrosomi Yamaguti, 1939 & AY627026 & Huys et al. (2006) \\
\hline & Hatschekia sp. & DQ538507 & Huys et al. (2007) \\
\hline \multirow[t]{5}{*}{ Kroyeriidae } & Kroyeria sp. & DQ538499 & Huys et al. (2007) \\
\hline & Kroyeria longicauda Cressey, 1970 & FJ447427 & Dippenaar (2009) \\
\hline & Kroyeria sphyrnae Rangnekar, 1957 & FJ447426 & Dippenaar (2009) \\
\hline & Kroyeria papillipes C. B. Wilson, 1932 & FJ447425 & Dippenaar (2009) \\
\hline & Kroyeria dispar C. B. Wilson, 1935 & FJ447424 & Dippenaar (2009) \\
\hline Lernaeopodidae & Parabrachiella bispinosa (Nordmann, 1832) & AY627027 & Huys et al. (2006) \\
\hline
\end{tabular}


Clavella adunca (Strøm, 1762)

Clavellopsis sp.

\section{Nanaspididae}

Nicothoidae

Pandaridae

Pennellidae

Pontoeciellidae

Sphyriidae

Outgroup

Cyclopidae

Mytilicolidae

Anthessiidae

Nanaspis tonsa Humes \& Cressey, 1959

Rhizorhina ohtsukai n. sp.

Rhizorhina soyoae n. sp.

Choniosphaera maenadis (Bloch \& Gallien, 1933)

Dinemoura latifolia (Steenstrup \& Lütken, 1891)

Pandarus smithii Rathbun, 1886

Perissopus dentatus Steenstrup \& Lütken, 1861

Achtheinus oblongus C. B. Wilson, 1908

Pseudopandarus longus (Gnanamuthu, 1951)

Pannosus japonicus (Shiino, 1960)

Phyllothyreus cornutus (Milne Edwards, 1840)

Nesippus orientalis Heller, 1865

Nesippus crypturus Heller, 1865

Nesippus vespa Cressey, 1964

Lernaeocera branchialis (Linnaeus, 1767)

Pontoeciella abyssicola (T. Scott, 1893)

Paeon elongatus C. B. Wilson, 1932

Apocyclops royi (Lindberg, 1940)

Euryte sp.

Trochicola entericus Dollfus, 1914

Pectinophilus ornatus Nagasawa et al., 1988

Synapticolidae

Anthessius sp.

Ectinosomatidae

Scambicornus sp.

Bradya sp.

Canthocamptidae

Bryocamptus pygmaeus (G. O. Sars, 1863)
AY627028 Huys et al. (2006)

HM545893 unpublished

AY627029 Huys et al. (2006)

LC054034 This study

LC054035 This study

DQ538509 Huys et al. (2007)

DQ538501 Huys et al. (2007)

DQ538502 Huys et al. (2007)

FJ447453 Dippenaar (2009)

FJ447452 Dippenaar (2009)

FJ447451 Dippenaar (2009)

FJ447450 Dippenaar (2009)

FJ447449 Dippenaar (2009)

FJ447445 Dippenaar (2009)

FJ447444 Dippenaar (2009)

FJ447443 Dippenaar (2009)

AY627030 Huys et al. (2006)

AY627031 Huys et al. (2006)

FJ447460 Dippenaar (2009)

AY626997 Huys et al. (2006)

AY626996 Huys et al. (2006)

AY627006 Huys et al. (2006)

AY627032 Huys et al. (2006)

AY627002 Huys et al. (2006)

AY627011 Huys et al. (2006)

AY627016 Huys et al. (2006)

AY627015 Huys et al. (2006) 
p6 p/1

rs 


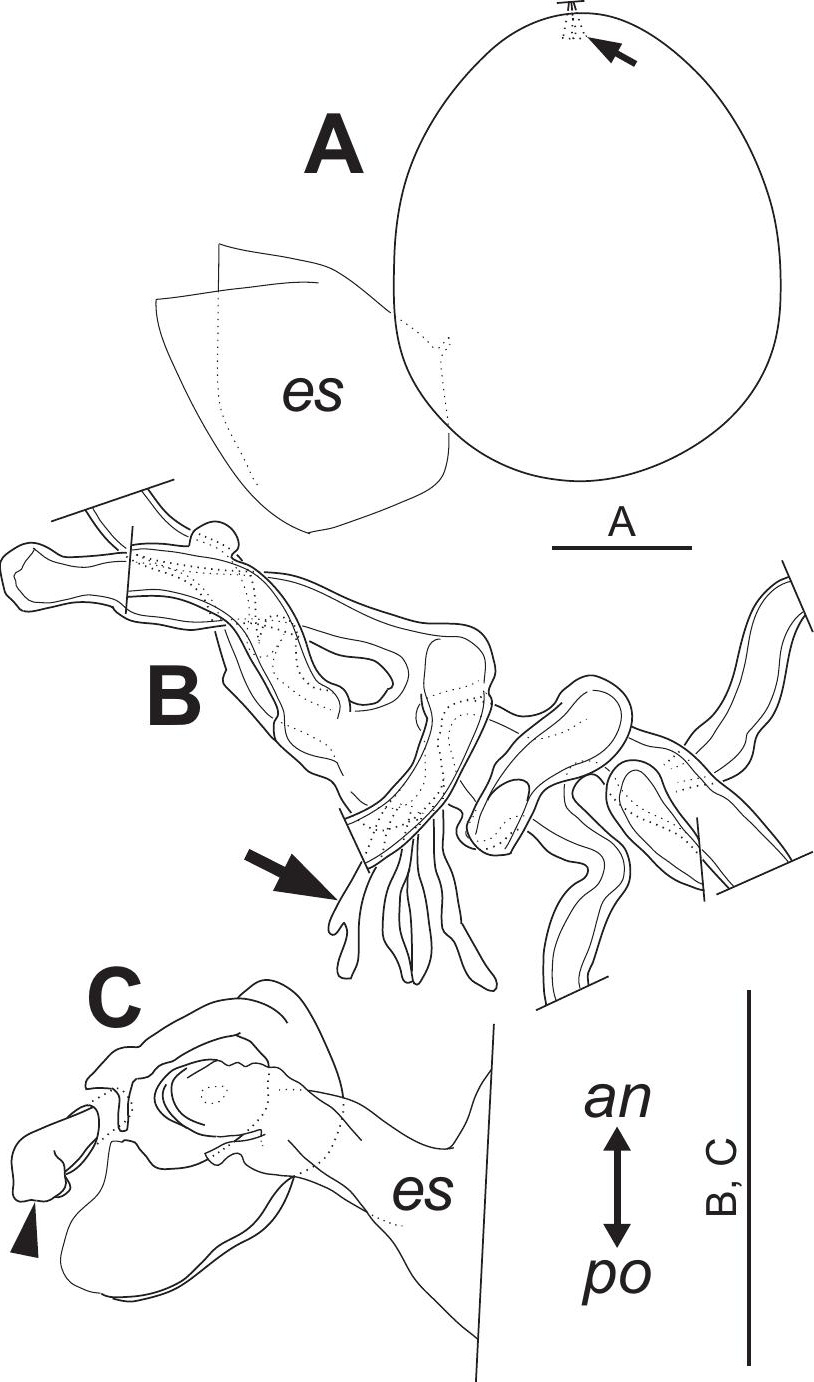




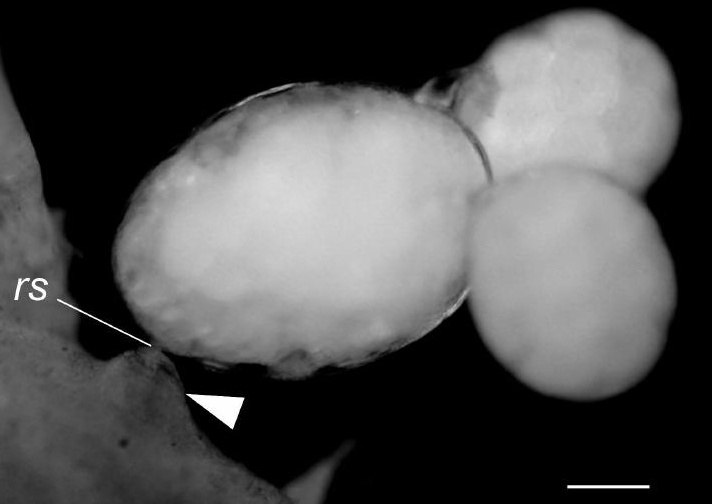




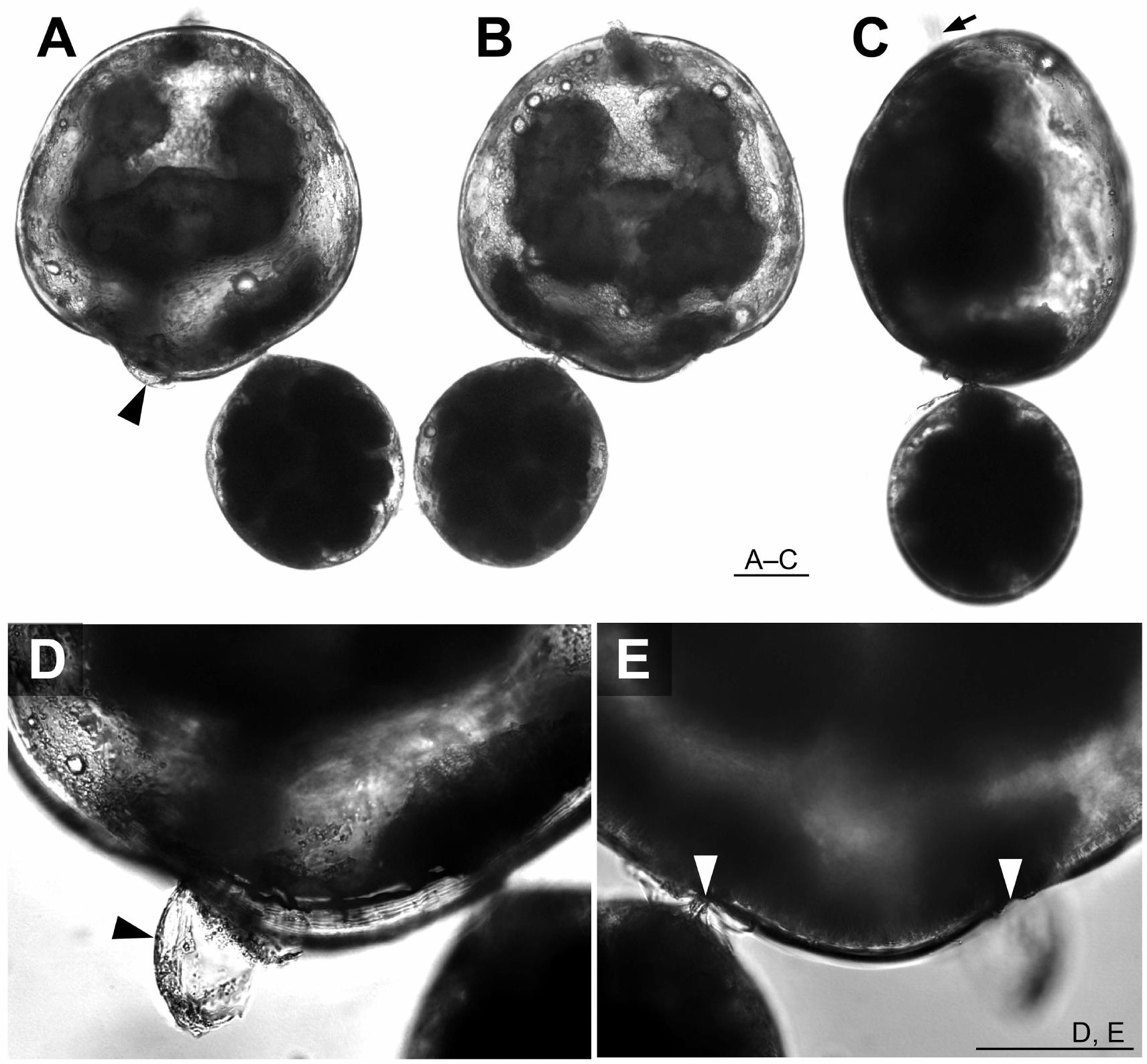





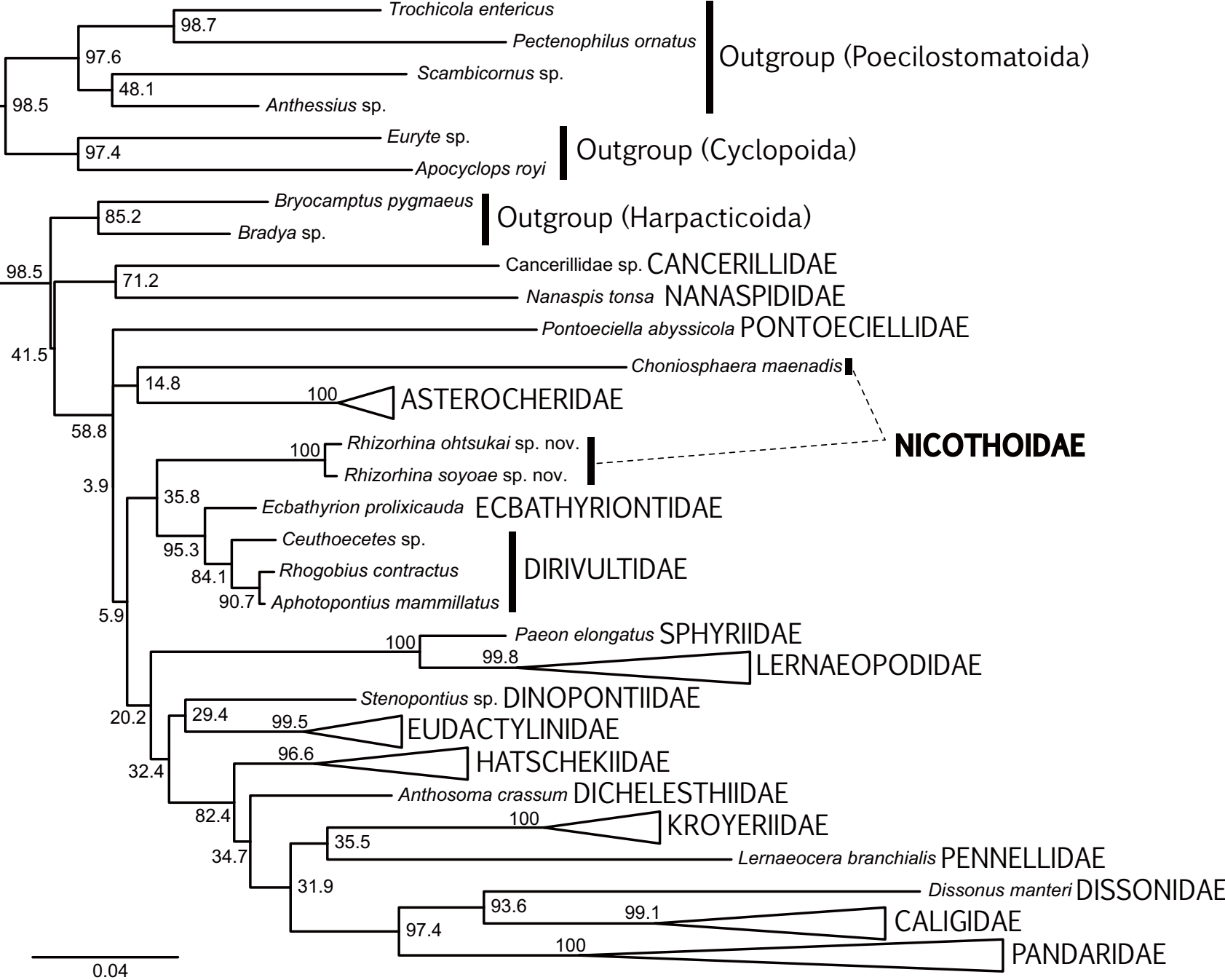

